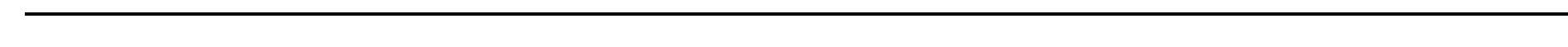

2 
Henna Makkonen-Craig*

\section{The forbidden first word: Discourse functions and rhetorical patterns of AND-prefacing in student essays}

https:// doi.org/ 10.1515/ text-2017-0024

Abstract: This article investigates AND-prefacing and its environments in student essays. Specifically, the focus is on those instances when a writer uses the Finnish ja 'and' as an opening element ("preface") to the sentence. While ANDprefacing is most commonly a single-usage feature employed by a small minority of writers in the essay genre analyzed here, the detailed functional-rhetorical analysis reveals a rich picture of these usages and the respective discourse norm that emerges and evolves in practice. This paper identifies eight micro-level discourse functions for AND-prefacing in the essays: (i) rhetorical, accumulative listing; (ii) emphasizing continuity of argument; (iii) dialogical aligning; (iv) unconventional intertextual linking; (v) evaluating a narrative turn; (vi) resolution; (vii) fantasy as coda; and (viii) plain cohesive linking. Significantly, AND-prefacing is not limited to the failed essays, nor to the low-graded essays more generally. The differences found in high- and low-graded (failed) essays may, however, suggest that some discourse functions and rhetorical patterns are associated with a higher institutional value than others. Methodologically, this study highlights the benefits of Rich Feature Analysis and dialogically oriented linguistic discourse analysis for exploring a relatively infrequent and yet distinctive rhetorical resource that has a complex form-function relationship in student essays.

Keywords: "rich feature", connective, conjunction, discourse norm, prescription, writing, genre

\section{Introduction}

This article investigates the use (and non-use) of the Finnish ja 'and' in the initial position of the sentence, as its preface. The term "prefacing" was first proposed by Heritage and Sorjonen (1994), who analyzed the contexts of ANDprefaced questions in institutional encounters. A more everyday label for the same phenomenon in written discourse is offered by Chang and Swales (1999).

*Corresponding author: Henna Makkonen-Craig, The Institute for the Languages in Finland, Hakaniemenranta 6, Fl-00530 Helsinki, Finland, E-mail: henna.makkonen-craig@kotus.fi 
In their study of informal elements of academic writing, they refer to sentenceinitial elements as initial conjunctions and as "forbidden first words" - inspiring the title of the current article.

Prefacing - especially opening a sentence with AND - is an interesting phenomenon from the point of view of writing cultures and their practices in the era of globalization. AND-prefacing is a controversial issue not only in the Finnish language and writing cultures, but also in other writing cultures such as the English/Anglo-American (see Chang and Swales 1999; Cotter 2003; Bell 2007), the Swedish (both Finland Swedish and Sweden Swedish) and the French (Tuomarla and Mahrer 2009), among others. Furthermore, this suggests that the social and pragmatic values assigned to AND-prefacing are under a process of re-evaluation and re-analysis (cf. Agha 2007), which is reflected in usage. For example, both print and screen-based public-sphere communications provide increasingly varying models, and in these circumstances, both professional and student writers engage in their strategic decision-making.

School writing is notoriously a domain where an evaluative dimension plays a crucial role. Its high-stakes test situations in particular provide interesting data for research, because both writers and assessors are likely to demonstrate a high degree of awareness of cultural, institutional and textual norms. The data for this study are drawn from Finnish mother tongue essays, also referred to as matriculation essays (see Section 3). To facilitate reading, the Finnish prefaced ja 'and' is referred to as AND-prefacing. The specific research questions are as follows:

1. Frequency of AND-prefacing: How common is AND-prefacing in matriculation essays?

2. Contexts of AND-prefacing: What are the discourse functions of AND-prefacing, and what types of rhetorical patterns are involved? Are there differences between high- and low-graded (failed) essays?

In its design, this study aligns with Rich Feature Analysis, an analytical approach where special attention is devoted to a qualitative, functional-rhetorical analysis of a "rich feature" in written discourse (E. Barton 2002; E. Barton 2004). In the context of this study, the identified "rich feature" is AND-prefacing. Furthermore, the qualitative approach of the present study can be described as dialogically oriented. This type of dialogical approach in linguistics highlights the dialogic, contextual and interactional dimensions of communication, focuses on language use rather than on its systemic description or abstract formalism, and operates within a larger dialogistic epistemological framework (Linell 2009; Evensen 2004; Makkonen-Craig 2014).

Before proceeding to the analysis and the findings, further background will be given on AND-prefacing and relevant literature will be reviewed (Section 2). 
This is followed by a discussion of the data and the analytical approach (Section 3). The empirical findings are then presented in two parts (Sections 4 and 5). The first part covers the overall findings regarding AND-prefacing in the essays, while the second part focuses on the qualitative, functional-rhetorical analysis of a smaller sample. Finally, conclusions are drawn in Section 6.

\section{Literature review}

\section{AND-prefacing}

Many grammars label items such as the Finnish ja 'and' and mutta 'but' as coordinating conjunctions. ${ }^{1}$ When these items open the sentence, they appear in its pre-front field and are commonly called connectives (ISK 2004: §1369). These prefacing connectives are non-obligatory from the grammatical point of view: their omission does not usually render the utterance or sentence ungrammatical. Early research on pragmatics and text linguistics referred to these initial items as "pragmatic" connectives or uses, and highlighted that the clause/sentence may then be connected to a larger text-segment than just another clause or sentence (Van Dijk 1979). Furthermore, this type of connective tends to explicate a semantic relation between steps in an argument rather than a relationship between processes (Halliday 1994: 338). In essence, these connectives are sequentially dependent items that organize discourse: they function in relation to the ongoing discourse, where they may operate on both local and more global levels (cf. "discourse markers," Schiffrin 2006).

Previous research has produced detailed qualitative analyses of AND-prefacing in spoken discourse (Schiffrin 1987; Schiffrin 2006; Heritage and Sorjonen 1994; on the Finnish ja, Kalliokoski 1989: 160-198; Korpela 2007: 190-197). In the field of written discourse, AND-prefacing has been identified in the letters by self-taught writers (Nordlund 2013: 127-133), written narratives told in a dialect (Kalliokoski 1998), newspaper columns and articles with a perspectival, audience-oriented style (Cotter 2003; Makkonen-Craig 2011), travel advertisements and fiction (Kalliokoski 1989: 199-230), and academic discourse (Chang and Swales 1999; Bell 2007). These studies have proposed various social and textual values to AND-prefacing, such as those in Table 1.

1 As conjunctions, these items are assumed to link coordinate units that are symmetrical and equal-sized elements, such as a clause with another clause, or a noun phrase with another noun phrase. 
Table 1: Social and textual values for AND-prefacing.

\begin{tabular}{|c|c|}
\hline everyday talk & $\begin{array}{l}\text { "linking turns" (by same or different speaker), "linking activities," } \\
\text { "change of perspective/ footing" }\end{array}$ \\
\hline $\begin{array}{l}\text { spoken narratives (after } \\
\text { pausing) }\end{array}$ & "turning-point," "change of perspective" \\
\hline $\begin{array}{l}\text { spoken institutional } \\
\text { encounters }\end{array}$ & "agenda-based question or action" \\
\hline $\begin{array}{l}\text { writing by self-taught } \\
\text { writers }\end{array}$ & "grassroots literacy," “turning-point" \\
\hline written fiction & "change of perspective or described activities," "continuity" \\
\hline written non-fiction & $\begin{array}{l}\text { "(dis)continuity," "change of perspective," "emphatic," "speech- } \\
\text { like," "interactional" }\end{array}$ \\
\hline
\end{tabular}

Furthermore, AND-prefacing is known to have a long history in biblical texts. Consider, for instance, the widely known and translated opening line of the following chapter "And it came to pass in those days, that there went out a decree from Caesar Augustus, that all the world should be taxed." (Luke 2:1). This usage reflects the rhetorical practices in the original source language, Hebrew (Kalliokoski 1989: 145 and references therein).

While research on spoken discourse has produced detailed qualitative analyses of AND-prefacing in specific encounters, in-depth qualitative analyses of AND-prefacing in written genres remain less common. An important step in this direction is David Bell's (2007) work on the sentence-initial And and But in journal articles. Drawing on Schiffrin (1987) and others, Bell examines three broad functional uses of And and But: (i) indicating the last item on the list; (ii) indicating the development of an argument; and (iii) indicating a discontinuity or shift.

Despite much interest in the area, there is a definite gap in knowledge about the actual environments and functions of rich features such as AND-prefacing in student essays.

\subsection{Discourse norms and prescriptive rules}

The Finnish sentence-initial ja 'and' is an item that Finnish writers are particularly aware of. This awareness is due to the common prescriptive rule that is taught to many generations of children and adults in Finland and is associated in particular with mother tongue instruction: "Do not begin your sentence with

2 Early work in discourse analysis saw the role of and as a default means for speakers to join together one-clause intonation units in a chain (Chafe and Danielewicz 1987: 103). More generally, this usage was said to reflect the spoken language characteristics of fragmentation (see Chang and Swales 1999: 149). 
ja ('and')."3 This normative lens has not, however, stopped writers from using AND-prefacing in many written contexts, such as in literary genres and children's stories, but also occasionally in non-fiction genres for adult audiences.

According to a sociocultural theory on norms, as outlined by Piippo, norms are understood as "concepts of appropriate, expected and meaningful conduct" (Piippo 2012: 30). The inherent assumption in this theory is that norms are both cognitive and social in nature: they involve mentally represented and hence cognitive knowledge, ideals and expectations, and yet, since they also involve socially shared knowledge, they are an integral part of the social and cultural reality of language (Piippo 2012).

Importantly, norms are found in all forms of human communication and in all levels of language (and language use). Taking Piippo's general definition of norms as a starting point, this study extends it to cover discourse, rhetoric and genre. Discourse norms are thus ideals, expectations and knowledge which concern genres, the discourses and the writers' rhetorical choices. Norms of this type make the text and discourse-level choices socially, culturally and, in this case, also institutionally meaningful and appropriate. In other words, discourse norms are an essential ingredient of genre awareness and genre knowledge (e.g. Tardy 2009; Devitt and Reiff 2014). Against this background it is clear that the simple prescriptive rule that forbids AND-prefacing is only one part of the social reality of school essays.

The institutional nature of the matriculation essays entails asymmetries of power. The student writer needs to be aware of the ideals that have been established by institutional gate-keepers (i.e. the Matriculation Examination Board and its examiners) and mediated by the teachers of mother tongue and literature. This includes, for example, what constitutes "good language," "good, mature writing" and "a good matriculation essay," and furthermore, how much leeway writers have. On the other hand, the students in their daily lives also interact with various out-of-school genres such as genres of fiction, screen-based communications and daily spoken interactions, and many of these genres commonly also enter the domain of school. At the same time, writers gain experience of different types of normative systems, each associated with a normative authority or body (e.g. school, a prescriptive grammar book, or the official Finnish language bureau), an influential collective (e.g. peer-group) or an individual (e.g. a teacher), or an abstract ideal (e.g. "proper Finnish" or "mature writing") (Blommaert 2005).

3 Many Finnish language users seem to take it for granted that the prescriptive rule regarding AND-prefacing is a codified norm of standard written Finnish in the same way as, for instance, the codified norms regarding the spelling of words, although this is not the case. 


\section{Methodology}

\subsection{Data context}

The data for the current study are drawn from matriculation essays written in senior high school in Finland. Currently, 50\% of Finland's 16-year-olds enter the senior high school and take the national matriculation examination at the end of their school. This examination has a dual function in the student's trajectory: it is perceived as a final test for previous studies and as a maturity test for further studies. The exam report and its grades play some role in the competition for places in tertiary education. One of the exams in the exam battery is the mother tongue test which currently has two parts: an essay test where candidates write a timed essay with pen and paper (maximum six hours), and a textual skills test on their analytical skills and interpretation of texts. The essay test focuses on the student's "general level of education, development of thinking, linguistic expression and coherency" (YTL 2017). ${ }^{4}$

Essay writing in school is an activity where texts and literacy play a significant role, making it a "literacy event" (Barton and Hamilton 2000). An essential characteristic of the Finnish matriculation essay is that the candidates not only orient to the evolving essay but also to the other relevant texts and genres in the event as well. A highly meaningful genre in this context is the writing prompt (task), the "initiating text" for the essay (Prior 2004: 173). The relationship of this initiating text and the essay can be likened to that of an "adjacency pair" in spoken interaction (cf. Schegloff 2007). The prompt constitutes the first part as it acts as a question or a directive, while the essay performs the second part as the answer or the accomplishment.

The candidates may select from a large number of prompts. Approximately half the prompts relate to the source material provided, which means that the test entails not only writing, but also critical cultural reading and the use of source material. The given source texts represent a variety of genres and texts, such as poems, short stories, song lyrics, media genres (for example, columns, articles and letters to the editor) and graphics. The writing event can hence be visualized as consisting of three types of textual artifacts: the writing prompt, the relevant source text(s) and the (un)folding essay (Figure 1).

4 The mother tongue exam can be taken in Finnish, Swedish or Saami. In addition, there is a separate test for second-language speakers. 


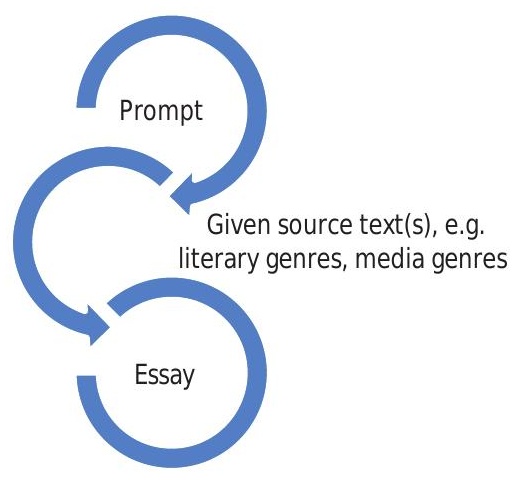

Figure 1: The textual artifacts in the literacy event.

The constellation of the literacy event has consequences for AND-prefacing and what counts as its textual anchor and "prior text" (Schiffrin 2006), as will be soon shown and discussed below.

The data analyzed for this study come from student essays that were written for the national matriculation examination in Finland in 1994, 1999 and 2004. These three annual samples comprise a total of 1,144 essays and over 525,000 words. The essays were written from 77 writing prompts. Each annual sample comprises essays from each given score, and is assessed on the scale of seven scores by the Matriculation Board. ${ }^{5}$ The label high-graded essays (HGEs) is used below to refer to essays given the highest scores (Laudatur, Eximia) on the exam, while low-graded essays (LGEs) have been assigned a low score or a fail (Lubenter, Approbatur, Improbatur). Each essay has also received a more specific score, on the scale of 47 to 99 points. The higher the score, the better quality of writing it represents.

The use of matriculation essays for research purposes is strictly regulated by the Matriculation Board, and a number of common codes of legislation govern the release of data. The researcher was granted a personal research permit for each annual sample (Decision Letters from 28 January 2008 to 6 June 2011). The Board's guidelines for storage, use and protection of the data were followed, and every effort was taken to conceal any information that could identify the candidate, the school or the assessor(s). More generally, the project followed at all stages the ethical guidelines of the University of Helsinki and Finnish Advisory Board on Research Integrity (TENK).

5 The scores from the highest to the lowest are referred to as Laudatur (=highest), Eximia, Magna, Cum Laude, Lubenter, Approbatur and Improbatur ( =fail). 


\subsection{Analytical approach: Rich Feature Analysis}

A fundamental part of Rich Feature Analysis (E. Barton 2002; E. Barton 2004) is to create a functional-rhetorical description of a focal, "rich" feature, in this case AND-prefacing. Two defining criteria are stated in the literature for a "rich feature," and AND-prefacing meets both of these criteria. The first criterion is its "linguistic integrity": AND-prefacing forms a linguistic category so that it can be linguistically defined, categorized and also counted, when required. The second criterion, "contextual value", is expressed more vaguely in prior literature but an important aspect is that the analysis highlights relevant information on the interconnection of form and function. AND-prefacing in school essays has added contextual value because it is a divisive issue that lacks consensus.

A distinctive characteristic of this type of discourse analysis is that qualitative and quantitative insights are used together (see E. Barton 2004 and references therein). This means that the study involves some numerical counts but not a full-blown quantitative method that would, for example, involve statistical analyses. The most fundamental and time-consuming stage for this type of research is developing a functional-rhetorical analysis. This stage is highly dependent on each particular research question and data, and it is therefore elaborated below (Section 5.1).

\section{General findings}

This section provides an overview of AND-prefacing in the essay data across the three years. In the analyzed 1,144 matriculation essays, which were written in the students' mother tongue Finnish, there occurred instances of nine different sentence-initial connectives. The sentence-initial ja 'and' is the second-most common $(n=266)$ prefacing connective, only preceded by the contrastive mutta 'but', which is nearly twice as common. ${ }^{6}$

In all essay samples, the dominant practice for writers was to avoid ANDprefacing completely. More specific accounts were available for the 2004 sample, where only one in eight students $(12 \%, n=47)$ used AND-prefacing one or more times in their essay. In other words, the vast majority (88\%) of the writers conformed throughout their essay to the common prescriptive rule. The second finding is that AND-prefacing tends to be a single-use

6 Interestingly, the English But and And came on the top of the list in the same order in the analyses by Bell (2007) and Chang and Swales (1999), who examined research articles written in English, published in different disciplines. 
feature, if used at all: the majority of those who employed AND-prefacing used it only once in their essay $(70 \%, \mathrm{n}=33)$, al though each essay contained numerous potential slots for AND-prefacing. Even the multiple users $(30 \%$, $\mathrm{n}=14$ ) employed AND-prefacing only two or three times. Significantly, ANDprefacing was not limited to the failed essays, nor to the low-graded essays more generally. Instead, it occurred in the essays with all scores, including the highest score, Laudatur.

The 1,144 essays were also divided into two groups according to the task type on one axis: whether the writing prompt required the use of source text(s). An interesting finding is that AND-prefacing was almost $30 \%$ more common in the group of texts that involved a given source text in the literacy event. It should be noted that essay length did not explain this difference: the essays that had assigned source texts were in fact shorter (on average) than the essays without given source texts, yet the former contained more instances of ANDprefacing. This finding is open to speculation: IS AND-prefacing due to a legitimate (or illegitimate) borrowing of resources from the source texts (e.g. fiction or media text)? Does it reflect the different cognitive and processual demands of the literacy event? The involved practices are certainly different in the two cases. In drawing on source texts for their own purposes, the writers must necessarily orient to other voices and opinions, and yet address the source texts in the manner that reflects the tradition of this institutional genre.

\section{A closer look at AND-prefacing: Discourse functions and rhetorical patterns}

In this section I will illustrate the micro-level discourse functions and rhetorical patterns of AND-prefacing in the essays. This qualitative, functional-rhetorical analysis is based on one annual sample, the essays written in the 2004 exam. In this sample 47 essays contain one or more instances of AND-prefacing (totaling 67 instances of AND-prefacing). The assigned scores are considered, too, because they indicate how these essays were received by the examiners.

\subsection{The functional-rhetorical analysis}

The functional-rhetorical analysis aims to obtain a plausible interpretation of the uses of the focal "rich feature" (E. Barton 2002; E. Barton 2004). This type of interpretation is the result of an analytic process based on the empirical data 
(essays and their careful reading) and an understanding that stems from previously reported research, as well as from cultural, contextual knowledge regarding both the writing situation and the relevant practices.

It is important to acknowledge that the qualitative analysis here does not impose a fixed, ready-made model on the data. Instead, it is better characterized as data-driven. In practice, the 47 essays were first read holistically, and the instances of AND-prefacing were grouped according to their pragmatic and semantic similarities and differences (see Makkonen-Craig 2011: 690). This reading focused on the meso-level organization of texts, that is, on paragraphs and topical sections where AND-prefacing was used. Relevant studies were consulted to explain and describe the identified patterns.

The qualitative approach undertaken here is further characterized as dialogically oriented. The analysis has been influenced by the writings of Bakhtin, and Linell (e.g. 2009), the sequential analysis employed in Conversation Analysis, and the work on "culturally popular patterns of discourse organization" by Hoey (2001) and others. (On the emergence and characteristics of this research orientation in Finland, see Makkonen-Craig 2014.)

The analysis is context-sensitive in that if the discourse function and the rhetorical pattern are particularly difficult to explain, the analysis will extend to consider the role of "other texts" in the literacy event. As indicated below, the source texts and the writing prompt form a dynamic interrelation with the essay and these "other texts" can provide important clues for explaining otherwise peculiar and incoherent AND-prefacing.

The following micro-level discourse functions for AND-prefacing were identified, based on the analyzed textual data:

- rhetorical, accumulative listing (5.2)

- emphasizing continuity of argument (5.3)

- dialogical aligning with a source text view (5.4)

- unconventional intertextual linking (5.5)

- evaluating a narrative turn (5.6)

- fantasy as coda (5.7)

- plain cohesive linking (5.8)

- resolution (see 5.5)

Before discussing further these micro-level discourse functions and the associated rhetorical patterns, a few preliminary remarks need to be made. First, this type of analysis does not aim to establish a clear-cut taxonomy. Instead, the purpose is to illustrate the discourse functions and the rhetorical patterns found in the data (in the given space). Furthermore, the discussion below focuses on cases that are interesting because they highlight an important aspect that relates to the 
contextual value of AND-prefacing in the focal genre, student essays, and more generally in educational writing (cf. the second criterion for a "rich feature" in 3.4). Second, specific quantitative accounts are not included in this section as these are rather uninformative, given the research design (sample size), and given the fact that AND-prefacing often has dual or multiple functions, as shown below. Finally, all the instances of AND-prefacing share a common discourse function, "linking." This is due to the basic semantics of the additive ja 'and' which remains and is maintained, even when it is used as a prefacing connective.

\subsection{Rhetorical, accumulative listing}

The first discourse function demonstrates a highly sophisticated rhetorical pattern and it is labeled as RHETORICAL, ACCUMULATIVE LISTING. Extract (1) gives an illustration: ${ }^{7}$

(1) Rakkaani, festivaalini (93 p, Laudatur)

[...] Suomen lyhyt kesä on yhtä tapahtumien riemukulkua, sillä juuri kesällä jokaisella on lupa nauttia ja juhlia välittämättä elämään asettamien realiteettien paineesta. [a] Kesäteattereissa rakastavaiset saavat toisensa, [b] juhlaviikoilla nyplätään metreittäin pitsiä, ja [c] puistoissa ja hiekkarannoilla sekä tanssitaan että lauletaan jazzin ja bluesin tahdissa. [d] Ja oluttelttoja nousee kuin sieniä sateella.

My beloved, the summer festivals

[...] The short summer in Finland is a triumph of events, for it is in the summer-time that everyone is allowed to enjoy themselves and celebrate despite the pressures brought on by the realities of life. [a] Lovers find each other in the summer theaters, [b] meters of bobbin lace are made during the town festival, and [c] people dance and sing to the rhythms of jazz and blues in the parks and on the sandy beaches. [d] And beer tents pop up like mushrooms in the rain. [END OF PARAGRAPH 6/15]

There are five points of particular interest in identifying the fully formed rhetorical pattern (cf. Kalliokoski 1989; Schiffrin 1994). The first is that this

7 The English translations of extracts maintain the tone of the original Finnish essays, even in the case of a failed essay. The deviations in spelling were not attempted in the translations, however. The translations may also involve strange metaphors, either because the metaphor was equally strange in the original language or because a close-enough common metaphor is not available in English. 
extract involves a description of a series of activities that are all linked together. This type of series in my data comprise three to five parts. In Extract (1), the list consists of four parts (as numbered). The second point is that there is semantic similarity or alikeness between the parts; in Extract (1), each part describes an activity that is common to the festivals. Third, there is also structural similarity; in other words, the parts are parallel and symmetrical in form (all finite clauses). The fourth point is that the fully formed pattern not only indexes semantic similarity, but also semantic difference; it indicates that the last part of the list pattern is somewhat different from the previous parts, and it is this difference that further motivates AND-prefacing. In Extract (1), the first three parts (a-c) describe the positive or neutral aspects of the festival, while the last part (d) implies that tensions are also involved; the last part introduces a negative or a potentially problematic aspect of festivals, which is further elaborated in the subsequent paragraphs of the essay. Finally, the full-blown pattern involves an escalation or a culmination of events and a high point of affect (and possibly irony). In other words, the list is accumulative.

In its fully developed forms, RHETORICAL, ACCUMULATIVE LISTING is confined to the highest score, Laudatur, in my data. More modest list patterns, which fulfill only some of the discussed criteria, are found in the low- and medium-score essays. In these cases, the list pattern involves a series of activities with semantic and structural similarity, but the essay lacks the high point of affect and the escalation or culmination of events. Furthermore, LGEs in my data have fractured lists, which may involve three recognizable parts; however, ANDprefacing is used in the middle (rather than linking the last part), or the form of the parts is highly asymmetrical (for example, one part is outstandingly long) or the parts are pragmatically too different (for instance, a declarative combined with interrogatives).

\subsection{Emphasizing continuity of argument}

While it can be argued that all the instances of AND-prefacing index the "continuity" of discourse, this subsection focuses on cases where AND-prefacing emphasizes this continuity and clarifies the developing argument and its steps. The involved pattern is built on claims and justifications. This discourse function, EMPHASIZING CONTINUITY OF AN ARGUMENT, is most evident when the prefaced ja 'and' forms a conjunction group, as in Extract (2) below. Companions of ja 'and' in the analyzed data are the Finnish equivalents of although, because and if. 
(2) Metsä - hoitaja vai hoidettava? (93 p, Laudatur)

[...] Luontoon, joka Suomessa tarkoittaa lähinnä metsää, on varastoitunut konkreettisen energian lisäksi valtavasti henkistä energiaa. Ainakin itse käyn usein latautumassa luonnon helmassa. Siellä voi rauhassa hiljentyä ja inmetellä Jumalan luomistyötä. Ja vaikka rauhallisen tunnelman tavoittaminen onnistuu myös tehokkaasti hoidetussa metsässä, ei ihmisen tulisi horjuttaa toiminnallaan liian paljon metsän luontaista tasapainoa. Useimmat metsänhoitajat osaavatkin kunnioittaa metsäänsä, sillä onhan metsä perinteisesti suomalaisille jollakin tavalla pyhä paikka.

Forest - a carer or a caree?

[...] Nature, which means mostly forest in Finland, not only supplies concrete energy, but also a tremendous amount of spiritual energy. I often re-charge my batteries in the hems of nature. There one can peacefully slow down and wonder at the creative work of God. And although one can also attain a peaceful atmosphere in an intensively cared forest, human beings should not disturb the natural balance of the forest too much. Most foresters do remember to respect their forest, for the forest is traditionally a kind of holy place for Finns. [PARAGRAPH 9/10]

Although AND-prefacing in this function occurs both in HGEs and LGEs, there are differences in the usage. In the analyzed HGEs, AND-prefacing indicates a further development of a lengthy argument (Extract [2]). In the LGEs, AND-prefacing connects relatively simple, short text segments (see Extracts [7] and [8]). This finding in general reflects the common differences of argumentation in the HGEs and LGEs.

\subsection{Dialogical alignment with a source text view}

The next discourse function, DIALOGICAL ALIGNMENT, is found in essays where the literacy event requires the use of one or more source texts (cf. Section 3). The sentence-initial AND in this function links two types of activities: quoting source text opinion, and expressing an invariably unconditional agreement. More precisely, the prefaced utterance is an authorial comment on the previous discourse (Bell 2007: 190), and this reactive comment displays alignment with a source text view and its writer (Extract [3]).

(3) Ammatiton alioppilas (57 p, Approbatur)

[...] [a] Juha Seppälä tekstissään kirjoittaa osuvasti näin: [b] "Kun ylioppilas valmistuu, sitä kohtaa järkytys ja kavala maailma". [c] ja se on aivan totta. 
[d] Yliopistoihin ei pääse ja töitäkin on vaikea saada ilman ammattia. Totuus paljastuu ylioppilaalle vasta sitten, kun haravointi vesisateisella hautausmaalla kastelee varpaat. [...]

Underachiever with no occupation

[...] [a] [The author] Juha Seppälä writes to the point in his text, like this: [b] "When a candidate graduates, he or she faces a shock and a treacherous world." [c] And it is quite true. [d] You can't get into the university and it is difficult to get a job without an occupation. The truth is revealed to the graduate only when raking leaves in a rainy cemetery soaks his toes. [...] [PARAGRAPH GOES ON ANOTHER LINES]

The DIALOGICAL ALIGNMENT in this extract is embedded in a rhetorical pattern consisting of four parts: (i) establishing a link with source text (and also evaluating the source, cf. writes aptly); (ii) quoting source text opinion; (iii) expressing unconditional agreement with the quoted opinion; and (iv) justifying opinion. AND-prefacing is used to connect the writer's agreement (iii) with the reported opinion (ii).

AND-prefacing in this discourse function is confined to LGEs in my data. Agreement with a source text view is, of course, a common act in all essays, but the HGEs employ a different rhetorical pattern for a similar purpose, as demonstrated by Juvonen (2010) and Mikkonen (2010: 105-106). This pattern involves concessions, embedding and the use of epistemic hedges. AND-prefacing in Extract (3) may even activate images of a different genre, such as casual conversation, blog text or causerie. ${ }^{8}$

\subsection{Unconventional intertextual linking}

The discourse function UNCONVENTIONAL INTERTEXTUAL LINKING occurs when the writer relies upon "other texts" in the literacy event in a manner that merges the essay with the "other text." Extract (4) below provides a case in point. ANDprefacing is used as on opening element of a new paragraph in the middle part of the essay. The prefaced utterance introduces a new topic, belt tiers, which has not been discussed previously in the essay, yet the writer treats the topic as

8 Two experienced examiners were interviewed concerning Extract (3). Their interpretation is that the writer has read the source text superficially and is using the "slicing style." It is expected and valued in this institutional genre that the writer internalizes and understands the meaning of the whole source text before writing the essay. 
though it were already familiar (cf. those belt tiers). On first sight, the essay appears to have a serious information gap, as if a whole section is missing.

(4) Keskitietä ystävien kanssa (63 p, Approbatur)

Ja ne vyönsitojat kun tulevat puheenaiheeksi, tässä tapauksessa nuorien vanhemmat, varmaankin tuntevat tehneensä kaikkensa, enkä sitä yhtään epäile. Nuorella saisi ja pitäisi olla niitä sitojia jonkin verran mutta liika, siinä missä liian vähäinenkin sitojien määrä johtaa hankaluuksiin. Nuorella olisi hyvä olla tukiverkosto. [...]

Stay the middle course with your friends

[NEW PARAGRAPH:] And when those belt tiers are considered, in this case the young people's parents, probably feel they have done all they can, and I have no doubt about it. The young person should have a certain number of those belt tiers but too many, just as too small number of tiers leads to difficulties. A young person ought to have a supporting network. [...] [PARAGRAPH / ]

As can be seen, coherence is established in Extract (4) by what is presented in the writing prompt. The prompt involves a biblical quote, and belt tiers were defined as a focal topic for the assignment. The writer's essay digresses from this topic in the first half of the essay. The AND-prefaced utterance in Extract (4) appears to indicate the writer's return to the agenda, and this usage resembles what Heritage and Sorjonen (1994) and Korpela (2007) discovered about AND-prefacing in institutional encounters, where it indicates "agendabasedness" (of questions). In other words, AND-prefacing here could be seen as normalizing of a problematic issue, and going back to the agenda (cf. Schiffrin 2006: 330, 332).

For the AND-prefaced utterances that are incoherent and apparently unmotivated, the coherence is provided by the writing prompt or the source text. This phenomenon could also be referred to as hidden coherence (Hoey 2001: 18-20; Juvonen 2010: 57). In both cases, the main issue is that the entire essay is not as independent a textual unit as is expected in this institutional context.

Intertextual linking to source texts as such is, of course, not limited to LGEs. A more poetic example appears in the title of an HGE: Ja Suomi tippui jaloilleen 'And Finland fell on its feet'. This title presents a synopsis of the writer's main argument in the essay, and in addition it provides an intertextual link to a source text, a popular song lyric entitled Kun Suomi putos puusta 'When Finland fell off the tree' (by Ismo Alanko) - as evidenced by the semantic similarity and syntactic parallelism of the two titles. In relation with the body 
of the essay, the AND-prefaced utterance has the discourse function of RESOLUTION: the utterance is a response to a problem presented in the essay, thus creating a problem-solution pattern (Hoey 2001). In this example, the prefaced ja 'and' has not only one but two textual anchors.

\subsection{Evaluating a narrative turn}

The next discourse function for the AND-prefaced utterance, EVALUATING A NARRATIVE TURN, is found mostly in the LGEs where the writer has adopted a narrative approach to the topic or has embedded a narrative in the essay. ANDprefacing occurs in critical phrases that evaluate an event in the story. These phrases include And suddenly... And not surprisingly... And it is only then that...

(5) Muistin jäljillä (65 p, Lubenter)

[..] Isällä puolestaan on erittäin ailahteleva muisti. Jos olemme lähdössä koko perheen voimin juhliin ja istumme jo autossa valmiina lähtöön, niin silloin isä muistaa unohtaneensa lompakon. Isä juoksee sisälle ja hetken kuluttua huutaa äidin avukseen, kun ei muista minne on lompakkonsa laittanut. Vihdoin lompakko löytyy ja olemme valmiit lähtöön. Ja kuinka ollakaan, isä muistaa kännykkänsä jääneen kotiin, ja taas käännetään koko talo ympäri. Ja vasta sitten olemme valmiit lähtemään. Onneksi olemme tottuneet isän toilailuihin ja lähdemme aina viisitoista minuuttia aikaisemmin, jotta isällä olisi aikaa palauttaa muistiin unohtamiaan tavaroita.

Tracing memory

[...] My father, on the contrary, has a very erratic memory. If we are ready to go to a party and the whole family sits already in the car, then my father will remember he forgot his wallet. He'll run in and after a while he'll shout for my mother, as he can't remember where his wallet is. Finally, the wallet will be found and we'll be ready to go. And not surprisingly, he'll then remember that his mobile phone is at home, and we'll turn the house upside down again. And it is only then that we'll be ready to leave. Luckily, we are used to his fooling around so we leave always fifteen minutes early, so that daddy has time to remember what he has forgotten. [END OF PARAGRAPH / ]

In this discourse function AND-prefacing is clearly associated with narratives and temporal orderliness, as it occurs in evaluative narrative clauses (Labov 1999; Ochs 2004; Schiffrin 2006: 320). The temporally organizing Finnish ja sit(ten) 'and then' 
(Extract [5]), is a common resource used by Finnish speakers in their stories (Kalliokoski 1989: 172-175).

A similar usage is found in argumentative micro-contexts where encapsulating evaluations such as And all this happens only because... And all this comes cheaply to our doors, with the pronouns all and this, have multiple discourse functions. Not only do they clarify the argument (cf. 5.3), but they also evaluate and bring closure to an argument (cf. 5.2).

\subsection{Fantasy as coda}

The next discourse function, FANTASY AS CODA, has two distinctive features. The first concerns its location: the AND-prefaced utterance appears as the final, concluding element in the essay. The other defining feature is that it involves a change of perspective (cf. Kalliokoski 1989). Extract (6) illustrates these two features:

(6) Kaksi suurta suomalaista (85 p, Magna)

[...] Vaikka Rafael Wardin ja Ilja Glazunovin työt ovatkin toisistaan poikkeavia, antavat ne silti hyvin todellisen kuvan kahdesta, suuresta ja rakkaasta suomalaisesta. Maalauksista heijastuvat erilaiset tunnelmat ja sävyt, antaen melko todenmukaiset mielikuvat kahdesta erilaisesta presidentistämme. Ja eihän sitä tiedä, vaikka seuraava presidenttimme voitaisiin maalata picassolaiseen tyyliin.

\section{Two great Finns}

[...] Although the works of Rafael Wardi and Ilja Glazunov are quite different, they give a very realistic picture of the two great and beloved Finns. The paintings reflect different atmospheres and shades, conveying rather true images of the two different presidents. And you never know, maybe our next president could be painted in the Picasso style. [END OF TEXT]

The change of perspective in Extract (6) is apparent in terms of the ongoing activities. The prior text involves descriptions, evaluative claims and justifications. With the prefaced utterance (And you never know maybe..), the narrator turns to look to the future, the world of imagination. Simultaneously, this utterance provides (a playful) closure to the ongoing argument as well as to the whole text.

\subsection{Plain cohesive linking}

The last discourse function, PLAIN COHESIVE LINKING, is associated with failed essays and more generally with the LGEs in my data. A distinctive feature is the 
clustering of numerous prefacing connectives in the same paragraph, as in Extract (7). In this micro-context, prefacing may indicate a continuous emphasis or a recurrent high point of affect (cf. 5.2).

(7) Tarviiko Internet rajoituksia? (50 p, Improbatur)

[..] Kokonaisuutta kun ajatellaan, niin ehkä rajoitukset ovat silti turhia. Sillä Internetin tiedon ja asian määrä on niin valtava, että rajoituksia olisi todella vaikea vahtia. Ja vaikka vahtiminen onnistuisikin, niin nykyään on ihmisiä, jotka käsittelevät tietokonetta niin hyvin, että heille ei tuottaisi ongelmaa kiertää rajoituksia. Ja nopeasti nämä konstit leviäisivät kaikkien korviin. Vaikka saataisiinkin ehdotusten avulla rajoituksia tehtyä, niin pian löytyisi lisää ja lisää syitä, mistä valittaa. Joten parempi on ehkä olla puuttumatta asiaan ollenkaan. Sillä ehkä Internettiin pätee sanonta"ei hyvää ilman pahaa".

Does the Internet need regulations?

[..] When we look at the whole, then maybe we do not need restrictions. Because/ As the amount of knowledge and information is so vast that it would be really difficult to keep a watch on the regulations. And even if you could watch them, there are these days people who manage the computer so well that it would be no problem for them to skip the regulations. And quickly these tricks would spread to everybody's ears. Even if we could make restrictions on the basis of suggestions, soon we would find more and more reasons to complain. So that maybe better not to intervene with the matter at all. Because the saying "there is nothing good without an evil side" is true when it comes to the Internet. [PARAGRAPH / , END OF ESSAY]

Another noteworthy feature is that AND-prefacing (and prefacing more generally) is used for tying together relatively small textual units (Extracts [7] and [8]). In Extract (8) below, it completes a list with only two elements (cf. 5.2).

(8) Nykyajan vahtikoirat (50 p, Improbatur)

[...] Tuomo Pietiläisen artikkelissa (Helsingin Sanomat 24.11.2002) kerrotaan kuinka gsm-operaattorit voivat paikallistaa kännykänhaltijan jopa sadan metrin tarkkuudella, mutta mitä gsm-operaattorit hyötyvät tästä? Pari syitä on esitetty: liikeyritykset haluavat hyödyntää tätä menetelmää lähettämällä erilaisia mainoksia ja tarjouksia. Ja yritykset, esimerkiksi vartiointi- ja jakeluyritykset, haluavat olla selvillä siitä, missä työntekijät liikkuvat.

Watch dogs of today

[...] Tuomo Pietiläinen's article (the Helsingin Sanomat 24.11.2002) tells how gsm operators can detect a mobile phone holder at the distance of 
100 meters, but how do the gsm operators benefit from this? A couple of reasons have been presented: business companies want to utilize this method by sending different kinds of advertisements and offers. And companies, such as security and delivery companies, want to know the whereabouts of their workers. [PARAGRAPH / ]

In this case, AND-prefacing appears to be a compensational device that is used in place of a more specific textual resource. In Extract (8), these more specific resources would have been "frame markers," such as first - second and one reason - another reason (e.g. Uccelli et al. 2013).

\section{Conclusion}

In this study, my goal was to answer two questions: How common is ANDprefacing in student essays? And more specifically: When AND-prefacing is used, what types of discourse functions and rhetorical patterns are involved? In line with Rich Feature Analysis, I began with a few quantitative insights for background information, and then focused on the detailed functional-rhetorical analysis of AND-prefacing.

Given the common belief that prefacing connectives in general are a spokenlanguage feature and that their strict absence is often considered a writtenlanguage feature (see Cotter 2003: 49), it is anticipated that the vast majority of writers do not use a single instance of AND-prefacing in their high-stakes essay. As it turns out, $88 \%$ of writers in my data were such non-users. What I did not expect, however, is that the remaining minority ( $12 \%$ of writers) who contested the common prescriptive rule would do this in such varied ways. In the analyzed sample, eight discourse functions and rhetorical patterns were identified for AND-prefacing, and even in this relatively small sample, some tendencies became clear.

First, writers who employed AND-prefacing did not seem to arrive at it from the same direction; instead, they drew on a variety of resource pools. Competing ideals, models and influences point to various genres, such as analytical and persuasive genres (cf. the discourse function EMPHASIZING CONTINUITY OF ARGUMENT), oral narratives and fiction (cf. EVALUATING A NARRATIVE TURN), and spoken interaction (cf. UNCONVENTIONAL INTERTEXTUAL LINKING and PLAIN COHESIVE LINKING), and many of these models are provided by the school institution itself. Second, an important and related finding is that AND-prefacing was not confined to failed essays or even low-graded essays. Instead, what 
seemed to differentiate HGEs from LGEs was how the writers used AND-prefacing. Out of the eight discourse functions for AND-prefacing, only two were found in essays with the highest grade, RHETORICAL ACCUMULATIVE LISTING and EMPHASIZING CONTINUITY OF ARGUMENT. In contrast, AND-prefacing with functions such as DIALOGICAL ALIGNING, EVALUATING A NARRATIVE TURN and PLAIN COHESIVE LINKING seemed to be associated with a lower value in this institutional, educational genre.

Building on a dialogical model of written communication (Evensen 2004), the next step for research could be an ethnographic one, to explore further the situational and also the situation-transcending meanings that student writers themselves assign to AND-prefacing (were such data available). Another direction to go is to explore the conceptualizations, experiences and evaluations of institutional gatekeepers. This includes not only mother tongue teachers and writing instructors but also professional writers such as journalists, non-fictions writers, editors and translators working in different languages and cultures. These experts play a key role in producing texts, and their work involves a sensitivity to and a constant re-orientation toward genres and discourse norms, as these professionals not only read but also create, edit and re-write texts for new audiences.

Acknowledgments: This research was financially supported by Emil Aaltonen Foundation. The author is grateful to Taru Nordlund, Irina Piippo, Susanna Shore, Anneli Kauppinen and the anonymous reviewers for their insightful comments on the manuscript.

\section{References}

Agha, Asif. 2007.

. Cambridge: Cambridge University Press.

Barton, David \& Mary Hamilton. 2000. Literacy practices. In David Barton, Mary Hamilton \& Roz Ivani (eds.),

, 7-15. London: Routledge.

Barton, Ellen. 2002. Inductive discourse analysis: Discovering rich features. In Ellen Barton \&

Gail Stygall (eds.),

19-42. Cresskill, N.J.: Hampton Press.

Barton, Ellen. 2004. Linguistic discourse analysis: How the language in texts works. In Charles Bazerman \& Paul Prior (eds.),

Bell, David. 2007. Sentence-initial

Blommaert, Jan. 2005.
, 57-82. New York: Routledge.

and in academic writing. 17(2). 185-201.

. Cambridge: Cambridge University Press.

Chafe, Wallace \& Jane Danielewicz. 1987. Properties of spoken and written language. In

Rosalind Horowitz \& S. Jay Samuels (eds.),

, 83-

113. San Diego: Academic Press. 

